\title{
WAWASAN YURIDIKA
}

Vol. 2 | No. 2 | September 2018 | Halaman : 127-147 http://ejournal.sthb.ac.id/index.php/jwy

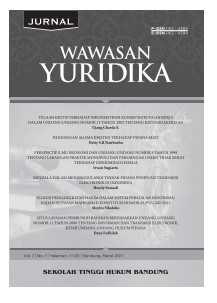

\section{Perlindungan Hukum Terhadap Kesempatan Kerja Bagi Masyarakat Lokal di Kota Cilegon}

\section{Fuqoha}

Universitas Serang Raya, Serang, Banten

Email: fuqoha23@gmail.com

\section{Info Artikel:}

Diterima: 6 Februari $2018 \quad$ IDisetujui: 27 September $2018 \quad$ IDipublikasikan: 29 September 2018

Kata Kunci:

Kesempatan kerja;

Masyarakat lokal;

Perlindungan hukum.

\begin{abstract}
Abstrak
Perlindungan hukum terhadap kesempatan kerja dan kesejahteraan masyarakat merupakan tanggung jawab negara. Dalam konsep otonomi daerah maka menjadi tanggung jawab bersama antara pemerintah pusat dan daerah untuk menciptakan peluang dan kesempatan kerja untuk memberikan kesejahteraan bagi masyarakat, khususnya masyarakat daerah atau lokal. Bentuk perlindungan hukum yang diberikan bagi masyarakat dapat berupa perlindungan hukum secara persuasif maupun represif. Berlandaskan pada konstitusi negara hingga peraturan perundangundangan telah diatur dan mengenai kesempatan kerja terhadap masyarakat lokal. Berarti perlindungan hukum terhadap kesempatan kerja secara persuasif telah dilakukan oleh pemerintah pusat dan daerah. Namun perlindungan hukum secara represif bagi masyarakat lokal dirasa belum terselenggara dengan maksimal yang mengakibatkan tingginya angka pencari kerja di daerah atau masyarakat lokal.
\end{abstract}

Keywords:

Employment opportunities; Legal protection; Local people.

\begin{abstract}
Legal protection of employement opportunities and welfare is the responsibility of the state. In the concept of regional autonomy it becomes the joint responsibility between the central and local governments to create opportunities and employment opportunities to provide welfare for the community, especially regional or local people. The form of legal protection afforded to the public may be a persuasive and repressive legal protection. Based on the state constitution until legislation has been regulated and on employment opportunities to the local people. This means that the legal protection of employment opportunities has been persuasive done by central and local governments. However, repressive legal protection for local people is not yet fully implemented, resulting in high numbers of job seekers for regional or local people.
\end{abstract}




\section{A. PENDAHULUAN}

Memperoleh pekerjaan merupakan hak bagi setiap orang untuk mengembangkan diri seperti dituangkan dalam Konstitusi Negara Republik Indonesia bahwa setiap warga Negara berhak atas pekerjaan dan penghidupan yang layak. Untuk memperoleh pekerjaan selain dibutuhkan keahlian dari para pekerja tentunya diperlukan peran pemerintah untuk mempersiapkan segala peluang kerja bagi masyarakat baik melalui peningkatan investasi dengan mengundang para investor untuk menanamkan modal dan membuka usaha di Indonesia maupun menciptakan lapangan pekerjaan yang diselenggarakan pemerintah melalui Badan Usaha Milik Negara (BUMN), Badan Usaha Milik Daerah (BUMD) maupun Perusahaan Swasta.

Pada hakekatnya setiap orang memiliki kesempatan yang sama untuk memperoleh pekerjaan serta menerima imbalan dari hasil pekerjaannya. Salah satu upaya untuk menjamin dan memberikan kesempatan kerja adalah adanya perlindungan hukum bagi masyarakat untuk mempertahankan hak sebagai warga negara untuk memperoleh pekerjaan. Adanya perlindungan hukum akan memberikan kepastian kepada setiap orang, baik pekerja maupun pengusaha dalam memberikan jaminan mengenai ketenagakerjaan.

Perlindungan hukum terkait hak setiap orang untuk memperoleh pekerjaan oleh pemerintah diatur melalui undang-undang tentang ketenagakerjaan. Adanya undangundang ini sebagai bentuk perlindungan pemerintah terhadap masyarakat dalam menjaga hak-hak setiap orang untuk memperoleh pekerjaan serta menjamin kesempatan dan mewujudkan kesejahteraan bagi setiap orang. Salah satu ketentuan dalam Undang-Undang Ketenagakerjaan mengatur tentang kesempatan kerja bahwa adanya-adanya pengaturan undang-undang ini sebagai perwujudan pemerataan kesempatan kerja dan penyediaan tenaga kerja yang sesuai dengan kebutuhan pembangunan nasional dan daerah.

Kesempatan kerja merupakan ketersediaan lapangan pekerjaan bagi para pencari kerja atau tenaga kerja. Berdasarkan ketentuan perundngundangan tenaga kerja yaitu setiap orang yang mampu melakukan pekerjaan guna menghasilkan barang atau jasa, baik untuk memenuhi kebutuhan sendiri maupun untuk masyarakat dan merupakan modal bagi bergeraknya perekonomian negara. Semakin berkembangnya iklim perekonomian negara dengan bertumbuhnya investasiinvestasi dalam dunia perindustrian, tentunya kesempatan kerja semakin terbuka bagi masyarakat guna memperoleh haknya dalam suatu pekerjaan. Kesempatan kerja yang terbuka tersebut harus diikuti dengan perlindungan dari pemerintah, baik dalam perlindungan hukum, kebijakan hingga memberikan dukungan maupun bantuan dalam mendapatkan pekerjaan. 
Dalam prinsip otonomi daerah yang dituangkan dalam Konstitusi Negara Republik Indonesia, dijelaskan bahwa pemerintah daerah diberikan kewenangan untuk mengatur dan mengurus pemerintahan seluas-luasnya kecuali yang diatur lain dalam undangundang. Dengan adanya otonomi daerah, maka pemerintah pusat dan pemerintah daerah secara bersamasama bertanggung jawab dalam rangka meningkatkan kesejahteraan rakyat. suatu daerah otonom sesuai ketentuan Konstitusi memiliki kewenangan untuk menyelenggarakan pemerintahan daerah.

Selain penyelenggaraan urusan pemerintahan, prinsip otonomi daerah juga bertujuan untuk meningkatkan kesejahteraan masyarakat. Salah satu indikator kesejahteraan masyarakat adalah tersedianya lapangan pekerjaan bagi masyarakat. Dengan adanya otonomi daerah, harapan untuk memperoleh kesejahteraan dalam bidang kesempatan kerja bisa lebih baik dan meningkat. Tentunya, hal tersebut harus didukung oleh peran pemerintah daerah dalam memperjuangkan hak masyarakat melalui penggunaan kewenangan daerah otonom secara tepat, bijak dan sesuai dengan yang diharapkan.

Kesempatan kerja yang diatur oleh pemerintah menunjukkan asas nondiskriminasi yang berarti seluruh warga Negara Indonesia memiliki kesempatan yang sama untuk memperoleh pekerjaan yang dijamin oleh Negara. Permasalahan yang muncul adalah iklim investasi tidak merata bagi wilayah-wilayah otonom yang mengakibatkan pola perpindahan masyarakat dari daerah yang satu ke daerah lainnya yang memberikan peluang kerja. Hal tersebut memberikan kehawatiran yang dapat menimbulkan persaingan yang kompleks dalam memperoleh pekerjaan.

Sebagai salah satu daerah otonom, Kota Cilegon mampu menjadi salah satu daerah yang memiliki potensi investasi yang sangat tinggi, salah satunya pertumbuhan di bidang perindustrian. Investasi yang tinggi dibidang industri tersebut memberikan persepsi bahwa Kota Cilegon sebagai kota industri yang terletak di provinsi Banten. Pertumbuhan industri di Kota Cilegon memberikan gambaran bahwa Kota Cilegon memberikan peluang dan kesempatan kerja yang sangat luas bagi setiap orang untuk memperoleh pekerjaan guna meningkatkan kesejahteraan kehidupan.

Dalam memperjuangkan pekerjaan, setiap orang memiliki kesempatan yang sama dan tanpa diskriminasi dalam kesempatan memperoleh pekerjaan. Peran pemerintah daerah sangat penting dalam membuat suatu kebijakan guna melindungi masyarakat lokal dalam memperoleh pekerjaan tanpa bertentangan dengan prinsip demokrasi. Di mana sesuai amanat Konstitusi setiap orang memiliki kesempatan yang sama dalam memperjuangkan hak-haknya. Perlu adanya suatu kebijakan daerah yang dapat memberikan perlindungan hukum bagi masyarakat lokal untuk 
mendapat kesempatan kerja di daerahnya sendiri.

Dalam prinsip otonomi daerah, salah satu semangat digulirkannya otonomi daerah yaitu dengan adanya otonomi seluas-luasnya masyarakat di daerah memiliki kesempatan untuk membangun daerahnya dalam rangka mewujudkan kesejahteraan masyarakat daerah. Salah satu upaya yang dilakukan oleh pemerintah daerah untuk menghidupi daerah dalam prinsip otonomi daerah adalah dengan meningkatkan pertumbuhan investasi para pelaku industri sehingga memberikan peluang kesejahteraan bagi masyarakat daerah.

Tantangan yang dihadapi pemerintah daerah bukan hanya persaingan yang datang dari dalam negeri atau pencari kerjadaridaerahlaindiIndonesia.Namun dengan adanya kesepakan pemerintah Indonesia tentang Masyarakat Ekonomi ASEAN (MEA) berakibat persaingan dengan Tenaga Kerja Asing (TKA). Oleh karena itu, tantangan pemerintah daerah Kota Cilegon semakin besar dalam melindungi masyarakat lokal untuk dapat memperoleh pekerjaan di daerah sendiri. Perlu suatu kebijakan yang tepat dan perlindungan hukum guna menghindari permasalahan ketenagakerjaan bagi masyarakat lokal di Kota Cilegon.

Persoalan hukum dalam rangka perlindungan terhadap kesempatan kerja masyarakat lokal terlihat dari kebijakan hukum pemerintah daerah Kota cilegon yang dituangkan dalam Peraturan Daerah Kota Cilegon Nomor 6 Tahun
2005 tentang Pelayanan Ketenagakerjaan Bidang Penempatan dan Pelatihan Tenaga Kerja yang membuka ruang bagi industri mempekerjakan tenga kerja dari luar daerah. Hal tersebut menunjukkan longgarnya perlindungan bagi masyarakat lokal di Kota Cilegon untuk memperoleh pekerjaan di daerah sendiri. Kehadiran pemerintah daerah dalam tugas pembantuan pemerintah pusat tentu harus memperkuat kedudukan dan kepentingan masyarakat daerah dalam rangka kesejahteraan masyarakat.

Dinamika perkembangan investasi industri di Kota Cilegon yang semakin tinggi, seharusnya memberikan peluang yang sangat besar bagi para pencari kerja secara nasional. Namun demikian, pemerintah Kota Cilegon perlu memperhatikan dan mempertimbangkan ketentuan dalam Pasal 4 Peraturan Daerah No. 6 Tahun 2005 terkait lowongan kerja yang tidak dapat dipenuhi masyarakat lokal karena faktor sumber daya manusia yang tidak sesuai keinginan industri. Sehingga para pencari kerja khususnya masyarakat lokal di mana industri dibangun dapat merasakan dampak dari kehadiran industri dalam memperoleh kesejahteraan.

Lemahnya perlindungan hukum terhadap kesempatan kerja mengakibatkan tingginya angka pencari kerja di Kota cilegon. Berdasarkan data yang dihimpun dari Badan Pusat Statistik (BPS) pada tahun 2016, jumlah pencari kerja yang terdaftar dalam Dinas Tenaga Kerja Kota Cilegon berjumlah 5.947 
orang. ${ }^{1}$ Banyaknya jumlah pencari kerja menunjukkan tidak tersedianya peluang kerja bagi masyarakat lokal. Selain itu, persentase angka pengangguran yang diperoleh dari pemerintah Kota Cilegon yakni mencapai 11,63\%. ${ }^{2}$ Hal tersebut sangat berbanding terbalik dengan fakta bahwa Kota Cilegon adalah kota industri. Industri jelas menjadi daya tarik bagi masyarakat Cilegon guna mencapai kesejahteraan di daerah sendiri.

Berdasarkan gambaran dari latar belakang yang dikemukakan tersebut, peneliti berupaya menganalisis bentuk perlindungan hukum terkait ketenagakerjaan. Daerah Cilegon sebagai kota industri berbanding terbalik dengan tingginya angka pencari kerja atau tingkat pengangguran bagi masyarakat lokal. Oleh karena itu, peneliti ingin mengetahui sejauh mana upaya perlindungan hukum oleh pemerintah daerah Cilegon bagi masyarakat lokal dalam memperoleh pekerjaan.

\section{B. METODE PENELITIAN}

Penelitian ini menggunakan pendekatan yuridis normatif dengan model penelitian kualitatif yang bersifat deskriptif analitis dengan maksud mengumpulkan data selengkap mungkin untuk menggambarkan fakta-fakta secara sistematis dan terintegrasi melalui data primer maupun data sekunder. ${ }^{3}$ Penelitian ini akan difokuskan pada upaya meningkatkan perlindungan hukum terhadap kesempatan kerja masyarakat lokal dalam prinsip otonomi daerah di Kota Cilegon. Dalam penelitian ini, bahan utama dalam penelitian normatif berupa peraturan perundangundangan dari tingkat pusat hingga daerah, baik yang dibuat oleh legislatif maupun eksekutif. ${ }^{4}$

\section{PEMBAHASAN}

\section{Negara Hukum dan Negara Kesejahteraan}

Pada hakekatnya manusia merupakan makhluk sosial yang saling membutuhkan antara manusia yang satu dengan yang lainnya. Oleh ahli filsafat Yunani sering disebutkan dengan kata zoonpoliticon yangberartimanusia sebagai makhluk sosial selalu ingin bergaul dan berkumpul dengan sesama manusia baik dalam konsep bermasyarakat maupun berbangsa. Kehidupan

1 Indonesia, Kota Cilegon Dalam Angka (Cilegon Municipality in Figure) 2016, Katalog/Catalog: 1102001.3672, hlm. 50.

2 Cilegon, "Pengangguran Capai 11,63 Persen, Walikota Cilegon Desak Industri Berdayakan Warga Lokal", https://wwww.bantennews.co.id/pengangguran-capai-1163-persen-walikota-cilegon-desak-industriberdayakan-warga-lokal/, diakses tanggal 9 Desember 2017.

3 Soerjono Soekanto, Pengantar Penelitian Hukum, Cet. Ke-3, (Jakarta: UI Press, 1986), hlm. 9-10.

4 Soerjono Soekanto dan Sri Mamuji, Penelitian Hukum Normatif, Ed. 1 Cet. 14, (Jakarta: Rajawali Press, 2012), hlm. 33. 
sosial bermasyarakat merupakan salah satu perbuatan manusia dalam rangka memenuhi segala kebutuhan dengan berkumpul dan bergaul untuk memenuhi kebutuhan hidup secara layak sebagai manusia. Karena manusia tentu saling membutuhkan satu dengan yang lainnya untuk mencapai kebutuhan hidup tersebut.

Untuk saling memenuhi kebutuhan sesama manusia, tentu memerlukan suatu hubungan kerja sama yang saling menguntungkan diantara kedua belah pihak. Kebutuhan dan kepentingan setiap manusia tidak selalu sama dalam rangka memenuhi kebutuhan untuk hidup secara layak. Oleh karena itu, sebagai makhluk sosial dalam lingkungan masyarakat dan bernegara agar kepentingan yang satu dengan yang lain tidak berbenturan diperlukan suatu aturan yang berfungsi untuk memelihara ketertiban dan ketentraman.

Dalam kehidupan bermasyarakat, sesungguhnya telah ada aturan-aturan bagi manusia untuk dapat hidup dengan tertib dan tentram seperti adanya norma atau kaidah keagamaan, adat istiadat, kesopanan dan kesusilaan. Norma atau kaidah merupakan pranata atau tatanan yang berkaitan dengan hubungan individu dalam hidup bermasyarakat. $^{5}$ Namun demikian, dalam suatu masyarakat terkadang berbeda keyakinan (agama) sehingga kaidah keagamaan tidak dapat dijadikan tatanan tunggal. Selain itu, masyarakat juga terkadang terdiri dari berbagai suku, adat isitiadat serta berbeda kebiasaan sehingga kaidah dan norma yang ada tidak mampu menjadi perlindungan bagi manusia agar terciptanya masyarakat dan Negara yang tertib dan tentram.

Untuk memelihara ketertiban dan ketentraman dalam hidup bermasyarakat, maka diperlukan suatu kaidah atau norma yang bersifat universal. Oleh karena itu, hukum dijadikan sebagai suatu tatanan bagi masyarakat untuk menertibkan masyarakatdalammencapaikepentingan dan kebutuhan. Kaidah hukum lahir dari gejala sosial yang ditimbulkan oleh tingkah laku manusia dalam mencapai kepentingannya, seperti disimpulkan oleh Chainur Arrasjid bahwa peraturan berasal dari tingkah laku manusia dalam pergaulan hidup bermasyarakat. ${ }^{6}$ Selain itu, hukum berfungsi melakukan tugas yaitu memberi jaminan bagi seseorang bahwa kepentingannya diperhatikan oleh orang yang lainnya. ${ }^{7}$ Dalam hidup bermasyarakat terdapat dua aspek yang menjadi kebutuhan manusia,

Peter Mahmud Marzuki, Pengantar Ilmu Hukum, Cet. Ke-5, (Jakarta: Kencana, 2013), hlm. 44.

Chainur Arrasjid, Dasar-Dasar Ilmu Hukum, Ed. 1 Cet. Ke-4, (Jakarta: Sinar Grafika, 2006), hlm. 22.

Ibid., hlm. 3. 
yaitu aspek fisik dan aspek eksistensi. ${ }^{8}$ Aspek fisik meliputi kebutuhankebutuhan fisik seperti makan, minum, mempertahankan diri, prokreasi, dan lainnya. Sedangkan aspek eksistensi, manusia membutuhkan pengakuan dari manusia lain maupun lingkungan.

Hukum memiliki sifat mengatur dan memaksa, karena adanya hukum untuk menjamin tata tertib dalam masyarakat. Kehidupan masyarakat dapat menjadi tertib dan teratur apabila ditunjang oleh tatanan hukum yang memberikan jaminan bahwa setiap manusia harus saling menghormati hak manusia lainnya, jika tidak menghormati dan mengindahkan tatanan hukum, maka akan ada sanksi atas perbuatannya tersebut. ${ }^{2}$ Perbedaan antara tatanan hukum dengan kaidah atau norma lainnya yaitu bahwa dalam tatanan hukum memiliki beberapa unsur antara lain (1) Peraturan berasal dari tingkah laku manusia dalam pergaulan masyarakat. (2) Peraturan dijalankan oleh badan resmi yang berwajib. (3) Peraturan berupa nilai-nilai dan konsepsi abstrak yang tertuang dalam bentuk perintah dan larangan. (4) Peraturan bersifat memaksa dan (5) Peraturan memiliki sanksi yang tegas dan nyata. ${ }^{10}$
Hukum dan masyarakat merupakan suatu yang tumbuh secara bersama dalam rangka menciptakan kerukunan, ketertiban dan ketentraman sebagai makhluk sosial. Untuk memenuhi kebutuhan dan kepentingan manusia dalam hidup bermasyarakat dan bernegara harus sesuai dengan aturanaturan hukum yang diciptakan dan dijadikan landasan sebagai tolak ukur suatu perbuatan manusia. Hukum dibutuhkan untuk menjadi jaminan bagi setiap orang dalam mempertahankan hak-haknya dalam kehidupan bersama dalam bermasyarakat dan bernegara.

Konsepsi negara hukum sesuai dengan amanat Undang-Undang Dasar 1945, bahwa negara Indonesia merupakan negara hukum yang dituangkan dalam Pasal 1 Ayat (3) Negara Indonesia adalah negara hukum. Konsepsi tersebut terbentuk dari kesepakatan masyarakat yang disepakati secara bersamasama melalui legislatif. Dalam konsep negara hukum sering dikenal dengan istilah rechtsstaat yang dikembangkan Kant, Stahl, Laband hingga Fitche dan istilah rule $f$ law yang dipelopori oleh A.V. Dicey. ${ }^{11}$ Konsepsi negara hukum dalam konsep rechtsstaat maupun rule of law menggambarkan bahwa hukum

\footnotetext{
Peter Mahmud Marzuki, Pengantar Ilmu Hukum ... op.cit., hlm. 42.

Chainur Arrasjid, Dasar-Dasar Ilmu ... op.cit., hlm. 4.

Ibid., hlm. 22.

11 Jimly Asshiddiqie, Hukum Tata Negara dan Pilar-Pilar Demokrasi, Ed. Kedua. Cet. Ke-2, (Jakarta: Sinar Grafika, 2012), hlm. 130.
} 
diadakan untuk memberikan jaminan bagi warga negaranya. Oleh karena itu, Undang-Undang Dasar 1945 sebagai hukum tertinggi negara menjadi tolak ukur perlindungan terhadap setiap warga negara.

Perlindungan hukum melalui konstitusi negara dalam prinsip negara hukum rechtsstaat menurut Stahl mencakup, (1) perlindungan hak asasi manusia; (2) pembagian kekuasaan; (3) pemerintahan berdasarkan undangundang; dan (4) peradilan tata usaha negara. Sedangkan dalam konsep rule of law mencakup (1) supremacy of law; (2) equality before the law; dan (3) due process of law. ${ }^{12}$ Berlandaskan pada konsepsi rechtsstaat maupun rule of law maka negara membutuhkan hukum sebagai landasan untuk memberikan kepastian hukum dan perlindungan hukum yang bertujuan untuk melindungi hak asasi manusia bagi setiap warga negara sesuai prinsip negara hukum.

Perkembangan prinsipnegarahukum terus berubah seiring perkembangan masyarakat. Utrecht membedakan dua macam negara hukum, yaitu negara hukum formil (tradisional) dan negara hukum materil (modern). ${ }^{13}$ Utrecht menggambarkan konsep negara hukum sebagai berikut:
Negara hukum formil menyangkut pengertian hukum yang bersifat formil dan sempit, melalui peraturan perundang-undangan tertulis. Tugas negara dalam negara hukum formil adalah melaksanakan peraturan perundang-undangan untuk menegakkan ketertiban. Sedangkan negara hukum materil mencakup pengertian yang lebih luas yang mencakup keadilan selain ketertiban. Tugasnya adalah menciptakan kesejahteraan rakyat (welfarestate). ${ }^{14}$

Kepentingan setiap orang berbedabeda antara satu dengan yang lainnya, jika tidak diatur oleh hukum maka akan menimbulkan benturan. Oleh karena itu, kepastian hukum menjadi suatu kebutuhan dalam pelaksanaan hidup bersama sebagai makhluk sosial. Selain itu, tugas negara tidak hanya menciptakan ketertiban tetapi negara mempunyai kewajiban untuk menciptakan kesejahteraan bagi seluruh rakyatnya.

Konsep welfarestate atau negara kesejahteraan merupakan cita-cita bangsa negara Indonesia. Konsepsi tersebut telah tertuang dalam amanat pembukaan konstitusi negara Indonesia di mana negara Indonesia memiliki

\footnotetext{
Ibid.

3 Ibid.

14 Ibid.
} 
cita-cita melalui Pembukaan UndangUndang Dasar 1945 Alenia IV “... membentuk suatu pemerintahan negara Indonesia yang melindungi segenap bangsa Indonesia dan seluruh tumpah darah Indonesia dan untuk memajukan kesejahteraan umum, mencerdaskan kehidupan bangsa ...".15 Oleh karena itu, konsepsi negara hukum dan negara kesejahteraan merupakan karakteristik dan tujuan dari bangsa dan negara Indonesia.

Negara kesejahteraan (Welfarestate) membebankan kepada negara Indonesia tanggung jawab sosial bagi seluruh warga negara untuk memperoleh kesejahteraan. Sehingga negara berdasarkan pada prinsip hukum formil maupun materil perlu melakukan pengaturan dan pembatasan dalam rangka mewujudkan kesejahteraan sosial sesuai amanat sila kelima dalam pancasila. Serta dalam prinsip otonomi daerah, maka pemerintah daerah sebagai penyelenggara pemerintahan yang memiliki kewenangan harus mampu mengendalikan kondisi daerah agar mampu menciptakan kesejahteraan bagi rakyat di daerahnya.

Melalui konsepsi negara hukum, maka akan tercipta peluang terselenggaranya kesejahteraan bagi masyarakat (welfarestate). Kesejahteraan bagi suatu negara tidak akan tercipta bilamana prinsip suatu negara tidak didasarkan pada prinsip negara hukum. Konsepsi negara hukum baik konsep rechtsstaat maupun rule of law menggambarkan bahwa hukum diadakan untuk memberikan jaminan bagi warga negaranya yang antara lain memberikan kesejahteraan bagi seluruh rakyat dan/atau warga negara.

Jaminan bagi seluruh warga negara merupakan bentuk perlindungan hukum yang diberikan oleh negara hukum. Konsekuensi suatu negara hukum yakni segala sesuatu dalam bentuk perbuatan dan kebijakan pemerintah dan/atau negara diatur melalui ketentuan hukum. Perlindungan hukum dapat diartikan sebagai perlindungan terhadap hak setiap orang untuk mendapatkan perlakuan dan perlindungan oleh hukum atau perundang-undangan. ${ }^{16}$ Oleh karena itu, keterkaitan antara perlindungan hukum dengan negara kesejahteraan tidak akan terlepas dari konsepsi negara hukum. Karena kesejahteraan negara tidak akan tercipta apabila tidak didukung dan dilindungi oleh ketentuan-ketentuan sebagai landasan pengambilan keputusan dan/ atau kebijakan.

15 Indonesia, Undang-Undang Dasar Negara Republik Indonesia 1945.

16 Aji Mulyana, "Perlindungan Hukum Terhadap Perempuan dan Anak Akibat Tindak Pidana Abortus Provocatus Criminalis", Jurnal Wawasan Yuridika Vol. 1 No. 2 (2017), hlm. 149. 
2. Prinsip Otonomi Daerah Dalam Menciptakan Peluang Kerja

Dalam sistem ketatanegaraan Indonesia, diatur ketentuan mengenai pembagian kekuasaan dalam bingkai Negara Kesatuan Republik Indonesia (NKRI) bahwa dalam rangka penyelenggaran pemerintahan dibagi atas daerah-daerah yang dapat mengatur dan mengurus sendiri urusan pemerintahan menurut asas otonomi dan tugas pembantuan. Dengan demikian, negara Indonesia dalam penyelenggaraan pemerintahan terdiri dari pemerintah pusat dan pemerintah daerah yang memiliki tugas dan kewenangan yang diatur oleh undang-undang. Secara umum dapat digambarkan bahwa pemerintah pusat menyelenggarakan pemerintahan nasional dan pemerintah daerah menyelenggarakan pemerintahan di daerah.

Dengan adanya otonomi daerah, maka pemerintah pusat dan pemerintah daerah secara bersamasama bertanggung jawab dalam rangka meningkatkan kesejahteraan rakyat. Suatu negara memiliki tujuan yang menurut Aristoteles bahwa negara itu ada untuk kepentingan warga negaranya, agar mereka dapat hidup baik dan bahagia. ${ }^{17}$ Oleh Epicurus, selain menyelenggarakan ketertiban dan keamanan, negara juga bertujuan untuk menyelenggarakan kepentingan perseorangan baik bersifat materialistis maupun bersifat kejiwaan dan kerohanian. ${ }^{18}$ Kepentingan warga yang materialistis mencakup kepentingan untuk memperoleh kesejahteraan, baik pendidikan maupun pekerjaan yang dijamin melalui konstitusi negara.

Suatu daerah otonom sesuai ketentuan Konstitusi memiliki kewenangan untuk menyelenggarakan pemerintahan daerah. Otonomi menurut Bagir Manan merupakan kebebasan dan kemandirian suatu pemerintahan yang berada dibawah pemerintah pusat untuk mengatur dan mengurus sebagian urusan pemerintahan. ${ }^{19}$ Namun demikian, kebebasan tersebut bukan suatu kemerdekaan bagi daerah yang diberikan oleh negara tetapi kebebasan untuk mengurus urusan rumah tangga daerah secara mandiri yang merupakan hakikat dari otonomi. ${ }^{20}$ Sesuai dengan ketentuan Konstitusi bahwa daerah diberikan kewenangan untuk mengatur dan mengurus pemerintahan seluasluasnya kecuali yang diatur lain

17 I Gde Pantja Astawa dan Suprin Na'a, Memahami Ilmu Negara Dan Teori Negara, Cet. Ke-1, (Bandung: Refika Aditama, 2009), hlm. 45.

18 Ibid., hlm. 46.

19 Agus Santoso, Menyingkap Tabir Otonomi Daerah Di Indonesia, Cet. Ke-1, (Yogyakarta: Pustaka Pelajar, 2013), hlm. 125.

20 Ibid. 
dalam undang-undang. Hal tersebut memberikan gambaran bahwa kebebasan yang diberikan dalam prinsip otonomi daerah tetap dibatasi oleh negara.

Untuk terlaksananya penyelenggaraan pemerintahan daerah sesuai amanat Undang-Undang Dasar maka perlu dilakukan pembagian kekuasaan antara pemerintah pusat dengan pemerintah daerah agar tidak saling tumpang tindih kewenangan antara pusat dan daerah. Pembagian kekuasaan oleh pemerintah pusat kepada pemerintah daerah dikenal dengan istilah desentralisasi. Menurut Irawan Soejito desentralisasi dibagi kedalam tiga macam yaitu: $:^{21}$

Pertama, desentralisasi teritorial yang merupakan pelimpahan kewenangan yang dilakukan pemerintah kepada suatu badan umum untuk menyelenggarakan pemerintahan sendiri. Kedua, desentralisasi fungsional yang merupakan pemberian kewenangan dari fungsi pemerintahan Negara atau daerah untuk diselenggarakan oleh suatu organ ahli yang khusus dibentuk untuk itu. Ketiga, desentralisasi administratif yang sering disebut dekonsentrasi yaitu pelimpahan sebagian kewenangan pemerintah pusat kepada alat perlengkapan atau organnya sendiri di daerah.
Pada prinsip desentralisasi teritorial negara memberikan kemandirian kepada daerah untuk mengatur dan mengurus daerah territorial disesuaikan dengan kepentingan masyarakat daerah. Setiap daerah memiliki karakteristik maupun kondisi daerah yang berbeda-beda yang memberikan kepentingan dan kebutuhan masyarakat yang berbeda. Setiap daerah atau teritorial juga memberikan jaminan dan kesejahteraan yang tidak sama, dimana hal ini yang mengakibatkan adanya pola urbanisasi masyarakat antar daerah demi jaminan dan kesejahteraan. Desentralisasi teritorial akan ditentukan oleh desentralisasi fungsional, dimana peran pemerintah daerah dalam menciptakan kesejahteraan juga perlu diimbangi dengan kepastian hukum bagi masyarakat daerah untuk memperoleh kesejahteraan.

Menjadi tanggung jawab dan kewenangan pemerintah daerah berkenaan dengan urusan menciptakan kesejahteraan masyarakat daerah sesuai dengan prinsip otonomi daerah bahwa pemerintah daerah diberikan kekuasaan dan kewenangan untuk mengatur dan mengurus daerah sendiri. Dalam penyelenggaraan urusan pemerintahan yang menjadi kewenangan pemerintah daerah terdiri dari urusan wajib dan urusan pilihan. Urusan pemerintah wajib artinya penyelenggaraan pemerintahan

${ }^{21} \quad$ Ibid., hlm. 118. 
berpedoman pada ketentuan undangundang dan kebijakan yang ditetapkan oleh pemerintah pusat. Sedangkan urusan pemeritahan yang bersifat pilihan meliputi urusan pemerintahan secara nyata dan berpotensi untuk meningkatkan kesejahteraan masyarakat sesuai dengan kondisi, kekhasan dan potensi unggulan daerah. ${ }^{22}$

Penyelenggaraan urusan wajib oleh pemerintah daerah beberapa diantaranya yang berkenaan dengan meningkatkan kesejahteraan masyarakat yaitu perencanaan dan pengendalian pembangunan, penanggulangan masalah sosial dan pelayanan pada bidang ketenagakerjaan. $^{23}$ Dalam prinsip otonomi daerah, salah satu semangat digulirkannya otonomi daerah yaitu dengan adanya otonomi yang seluasluasnya dalam menyelenggarakan pemerintahan sendiri, sehingga masyarakat di daerah memiliki kesempatan untuk membangun daerahnya dalam rangka mewujudkan kesejahteraan masyarakat daerah.

Dalam penyelenggaraan pemerintahan daerah tidak terlepas pada faktor pemimpin daerah atau disebut dengan kepala daerah. Seorang kepala daerah tentu harus memiliki sikap aktif dan komunikatif dalam melaksanakan kekuasaan dan kewenangannya. ${ }^{24}$ Pemimpin dituntut mampu menyusun kebijakan pembangunan, pemberdayaan dan pelayanan bagi masyarakat. Selain itu, pemimpin harus mampu mengimplementasikan kebijakan serta mengevaluasi demi tercapainya tujuan pemerintahan dalam mensejahterakan masyarakat. Dalam pelaksanaan otonomi daerah, pemerintah daerah tidak hanya berorientasi guna memperoleh kewenangan yang diberikan oleh undang-undang semata. Namun, esensi dan tujuan adanya otonomi daerah adalah untuk memberikan pelayanan yang lebih baik bagi masyarakat daerah dalam rangka mencapai kesejahteraan masyarakat.

Konsepsi otonomi daerah memberikan hak, wewenang dan kewajiban bagi daerah untuk mengurus dan mengatur rumah tangganya sendiri sesuai dengan peraturan perundang-undangan yang berlaku. ${ }^{25}$ Oleh karena itu, untuk memberikan peluang dan kesempatan dalam ketenagakerjaan, pemerintah daerah harus mampu mengatur mekanisme penempatan maupun

22 Siswanto Sunarno, Hukum Pemerintahan Daerah Di Indonesia, Cet. Ke-4, (Jakarta: Sinar Grafika, 2012), hlm. 35 .

23 Ibid.

24 J. Kaloh, Kepemimpinan Kepala Daerah, Ed. 1 Cet. Ke-1, (Jakarta: Sinar Grafika, 2009), hlm. 13.

25 Darwin Ginting, "Konsepsi Otonomi Daerah Sebagai Alternatif Pilihan Dari Tuntutan Bentuk Negara Federal Di Indonesia", Jurnal Wawasan Yuridika Vol. 25 No. 2 (2011), hlm. 349. 
kesempatan kerja bagi masyarakat daerah.

Memperoleh pekerjaan diatur dalam konstitusi negara Pasal 28D Ayat (2) bahwa setiap orang berhak untuk bekerja serta mendapat imbalan dan perlakuan yang adil dan layak dalam hubungan kerja. Ketentuan konstitusi tentu menjadi landasan hukum bagi seluruh rakyat Indonesia dalam prinsip demokrasi konstitusional. Negara menjamin setiap orang Indonesia memiliki kesempatan yang sama untuk memperoleh pekerjaan sesuai konsepsi rechtsstaat maupun rule of law. Namun konsepsi negara hukum tersebut harus dimaknai sebagai suatu kepastian bagi setiap warga negara Indonesia yang diimbangi prinsip otonomi daerah yang memberikan kewenangan kepada daerah untuk menciptakan kondisi daerah sesuai kepentingan rakyat di daerah.

Sebagai negara hukum peran pemerintah dalam menciptakan kesempatan kerja diatur melalui Undang-Undang Nomor 13 Tahun 2003 tentang ketenagakerjaan Pasal 1 Ayat (2) “Tenaga kerja adalah setiap orang yang mampu melakukan pekerjaan guna menghasilkan barang dan/atau jasa baik untuk memenuhi kebutuhan sendiri maupun untuk masyarakat". Selanjutnya dalam Pasal 5 disebutkan "Setiap tenaga kerja memiliki kesempatan yang sama tanpa diskriminasi untuk memperoleh pekerjaan" ${ }^{26}$

Berlandaskan pada kepastian hukum tentang ketenagakerjaan, maka perlindungan hukum terhadap kesempatan kerja bagi masyarakat dapat terlaksana. Sesuai dengan tujuan pemerintah dari pembentukan undangundang Nomor 13 Tahun 2003 tentang ketenagakerjaan yang antara lain:

Pertama, memberdayakan dan mendayagunakan tenaga kerja secara optimal dan manusiawi. Kedua, mewujudkan pemerataan kesempatan kerja dan penyediaan tenaga kerja yang sesuai dengan kebutuhan pembangunan nasional dan daerah. Ketiga, memberikan perlindungan kepada tenaga kerja dalam mewujudkan kesejahteraan. Dan keempat, meningkatkan kesejahteraan tenaga kerja dan keluarganya. ${ }^{27}$

Prinsip otonomi daerah dalam bidang ketenagakerjaan telah diatur dalam ketentuan undang-undang yang dituangkan dalam Lampiran UndangUndang Nomor 23 Tahun 2014 tentang Pemerintahan Daerah dalam pembagian urusan bidang ketenagakerjaan antara pemerintah pusat, pemerintah provinsi dan pemerintah kabupaten/kota.

\footnotetext{
26 Indonesia, Undang-Undang Nomor 13 Tahun 2003 tentang Ketenagakerjaan.

27 Ujang Chandra, Karakteristik Undang-Undang Ketenagakerjaan Dalam Perlindungan Hukum Terhadap Tenaga Kerja, Jurnal Wawasan Yuridika Vol. 32 No. 1 (2015), hlm. 2.
} 
Dengan demikian, amanat UndangUndang Nomor 13 Tahun 2003 Tentang Ketenagakerjaan mengenai hak setiap orang untuk memperoleh pekerjaan menjadi tanggungjawab pemerintah daerah.

Sinergitas antara ketentuan undangundang serta kewajiban pemerintah daerah dalam memberikan peluang dan kesempatan kerja sebagai bentuk perlindungan kepada tenaga kerja dalam mewujudkan kesejahteraan. ${ }^{28}$ Perlindungan masyarakat menjadi salah satu tanggungjawab dan kewenangan pemerintah daerah, termasuk persoalan ketenagakerjaan yang diatur dalam Pasal 12 Ayat (1) huruf e dan Ayat (2) huruf a Undang-Undang Nomor 23 Tahun 2014 Tentang Pemerintah Daerah.

Konsekuensi kewajiban pemerintah daerah terhadap undangundang ketenagakerjaan antara lain melaksanakan pelatihan sumber daya manusia berdasarkan unit kompetensi, pengukuran produktivitastingkat daerah kabupaten/kota, pelayanan antar kerja di daerah kabupaten/kota, pengelolaan informasi pasar kerja dalam daerah kabupaten/kota, pengesahan peraturan perusahaan dan pendaftaran perjanjian kerja bersama untuk perusahaan yang ada di kabupaten/kota dan pencegahan dan penyelesaian perselisihan hubungan industrial, mogok kerja dan penutupan perusahaan di daerah kabupaten/kota. ${ }^{29}$

Dengan adanya kepastian hukum bagi masyarakat untuk memperoleh pekerjaan, maka peran pemerintah pusat dan pemerintah daerah adalah memastikan bahwa peluang dan kesempatan kerja bagi masyarakat di daerah masing-masing dapat menciptakan kesejahteraan bagi masyarakat di daerahnya dan secara umum kesejahteraan bagi seluruh rakyat Indonesia. Dengan prinsip otonomi seluas-luasnya maka peran pemerintah daerah baik melalui kepala daerah dalam desentralisasi fungsional maupun melalui lembaga/alat pemerintah pusat dalam desentralisasi administratif harus mampu menciptakan peluang kerja bagi masyarakat daerah masing-masing.

\section{Perlindungan Hukum Terhadap Kesempatan Kerja Masyarakat Lokal}

Maria Theresia Geme mengartikan bahwa perlindungan hukum berkaitan dengan tindakan negara untuk melakukan sesuatu (memberlakukan hukum secara ekslusif) dengan tujuan

28 Ibid.

29 Indonesia. Lampiran Undang-Undang Nomor 23 Tahun 2014 tentang Pemerintahan Daerah. Pembagian Urusan Pemerintahan Konkuren antara Pemerintah Pusat dan Daerah Provinsi dan Kabupaten/Kota. Sub G Pembagian Urusan Pemerintah Bidang Tenaga Kerja. 
untuk memberikan jaminan kepastian hak-hak seseorang atau sekelompok orang. ${ }^{30}$ Perlindungan hukum diartikan juga sebagai perlindungan hak setiap orang untuk mendapatkan perlakuan dan perlindungan oleh hukum atau perundang-undangan. ${ }^{31}$

Bentuk perlindungan hukum pemerintah terhadap kesempatan kerja bagi warga negara Indonesia kemudian diatur melalui undang-undang ketenagakerjaan bahwa pemerintah pusat dan daerah bertanggung jawab mengupayakan perluasan kesempatan kerja. Dengan demikian maka setiap warga negara memiliki hak untuk memperoleh pekerjaan, terlebih bagi masyarakat di mana daerah menjadi daerah industri memiliki kesempatan untuk memperoleh pekerjaan demi kesejahteraannya.

Tugas dari pemerintah pusat dan daerah yaitu menciptakan kesempatan kerja seluas-luasnya bagi masyarakat. Kesempatan kerja merupakan bentuk lowongan pekerjaan yang dapat diisi oleh pencari kerja dan/atau pekerja yang sudah ada. Upaya pemerintah yaitu menciptakan perluasan kesempatan kerja dengan upaya yang dilakukan untuk menciptakan lapangan pekerjaan baru dan/atau mengembangkan lapangan pekerjaan yang tersedia. ${ }^{32}$

Prinsip otonomi daerah yang memberikan kesempatan bagi daerah untuk mengurus dan menyelenggarakan urusan daerah demi terciptanya kesejahteraan. Kesejahteraan masyarakat dapat diperoleh salah satunya dengan memiliki pekerjaan yang layak. Diantara daerah yang memberikan kesempatan atau peluang kerja di Indonesia yaitu Kota Cilegon. Kota Cilegon sebagai salah satu kota di provinsi Banten yang dijuluki sebagai kota baja maupun kota industri menjadi daya tarik bagi masyarakat Banten maupun warga negara Indonesia guna meningkatkan kesejahteraan melalui ketenagakerjaan.

Salim menjabarkan bentuk perlindungan hukum kedalam dua bentuk, yaitu perlindungan preventif dan perlindungan represif. ${ }^{33}$ Perlindungan hukum secara preventif terhadap kesempatan kerja masyarakat lokal berarti pemerintah bersama-sama dengan masyarakat menciptakan suatu kebijakan yang dapat mencegah terjadi hilangnya hak masyarakat lokal untuk dapat memperoleh pekerjaan di daerah

30 Salim dan Erlies Septiana Nurbani. Penerapan Teori Hukum Pada Penelitian Tesis Dan Disertasi. Cetakan Ke-2 (Jakarta: Raja Grafindo Persada, 2013), hlm. 262.

31 Aji Mulyana, "Perlindungan Hukum..., op.cit., hlm. 149.

32 Indonesia, Peraturan Pemerintah No. 33 Tahun 2013 tentang Perluasan Kesempatan Kerja. Pasal 1 Ayat (1) dan (2).

33 Salim dan Erlies Septiana Nurbani. Penerapan Teori Hukum ... op.cit., hlm. 264. 
sendiri. Bentuk perlindungan preventif ini menggambarkan bahwa secara materil harus terdapat ketentuan yang menjamin masyarakat lokal diberikan kesempatan kerja tanpa menghalangi kesempatan kerja bagi masyarakat dari luar daerah.

Kedua, adanya perlindungan represif yang berarti pemerintah selaku pemilik kewenangan dan otoritas tertinggi di daerah harus mampu menyelesaikan persoalanhilangnyahakataukesempatan kerja masyarakat lokal di daerah sendiri. Pemerintah daerah sebagai pembentuk kebijakan harus mampu menyelesaikan persoalan hak kesempatan bekerja yang terjadi pada masyarakat daerah. Sesuai dengan konsep negara hukum yang diungkapkan oleh Jimly Asshiddiqie secara formil pemerintah menjalankan aturan hukum sebagai kepastian dalam melindungi kesempatan kerja masyarakat lokal dan secara materil pemerintah daerah wajib memberikan kesejahteraan bagi masyarakat lokal atau daerah.

Angka pencari kerja atau pengangguran di Kota Cilegon yang mencapai $11,63 \%$ menunjukkan lemahnya perlindungan hukum baik secara preventif maupun represif yang dilakukan oleh pemerintah Kota Cilegon. ${ }^{34}$ Sebagai kota atau daerah yang dijuluki kota industri, Cilegon menjadi salah satu daerah yang menjadi daya tarik investasi. Menurut Data Badan Pusat Statistik (BPS) Kota Cilegon jumlah perusahaan sebagai berikut:

Tabel 1. Jumlah Perusahaan Di Kota Cilegon

\begin{tabular}{|c|c|c|}
\hline No. & $\begin{array}{c}\text { Klasifikasi Industri / } \\
\text { Classification Industrial }\end{array}$ & $\begin{array}{c}\text { Jumlah } \\
\text { Perusahaan / } \\
\text { Establishments }\end{array}$ \\
\hline 1 & Makanan/Food & 9 \\
\hline 2 & Minuman/Beverage & 1 \\
\hline 3 & Konveksi & 1 \\
\hline 4 & $\begin{array}{l}\text { Kayu dan barang dari } \\
\text { kayu (tidak termasuk } \\
\text { furniture) dan barang } \\
\text { anyaman dari bamboo, } \\
\text { rotan dan sejenisnya }\end{array}$ & 1 \\
\hline 5 & $\begin{array}{l}\text { Produk dari batu bara dan } \\
\text { pengilangan minyak bumi }\end{array}$ & 4 \\
\hline 6 & $\begin{array}{l}\text { Bahan kimia dan barang } \\
\text { dari bahan kimia }\end{array}$ & 27 \\
\hline 7 & $\begin{array}{l}\text { Karet, barang dari karet } \\
\text { dan plastik }\end{array}$ & 3 \\
\hline 8 & $\begin{array}{l}\text { Barang galian bukan } \\
\text { logam }\end{array}$ & 7 \\
\hline 9 & Logam dasar & 8 \\
\hline 10 & $\begin{array}{l}\text { Barang logam, bukan } \\
\text { mesindan peralatannya }\end{array}$ & 13 \\
\hline 11 & Peralatan listrik & 1 \\
\hline 12 & Mesin dan perlengkapan & 3 \\
\hline 13 & $\begin{array}{l}\text { Kendarang bermotor, } \\
\text { trailer dan semi trailer }\end{array}$ & 1 \\
\hline & Kota Cilegon & 79 \\
\hline
\end{tabular}

Sumber: Kota Cilegon Dalam Angka (Cilegon Municipality in Figure) 2016. hlm. 133.

34 Cilegon. "Pengangguran Capai 11,63 Persen, Walikota Cilegon Desak Industri Berdayakan Warga Lokal", $\quad$ https://www.bantennews.co.id/pengangguran-capai-1163-persen-walikota-cilegon-desak-industriberdayakan-warga-lokal/, diakses tanggal 9 Desember 2017. 
Dengan jumlah perusahaan yang begitu banyak di Kota Cilegon menunjukkan upaya pemerintah melalui undang-undang ketenagakerjaan telah dilaksanakan oleh pemerintah pusat dan daerah. Pemerintah berupaya untuk menciptakan perluasan kesempatan kerja dengan memberikan peluang investasi yang terbuka di daerah. Namun, seharusnya perluasan kesempatan kerja perlu didukung dengan kepastian terkait mekanisme perekrutan tenaga kerja bagi masyarakat lokal atau masyarakat daerah di mana investasi tersebut dibangun.

Perlindungan hukum pemerintah daerah Kota Cilegon seperti dikemukakan Maria Theresia Geme bahwa perlindungan hukum berkaitan dengan tindakan untuk melakukan sesuatu dengan memberlakukan hukum secara ekslusif dengan tujuan untuk memberikan jaminan kepastian hak bagi masyarakat lokal di Kota cilegon. Sejauh ini bentuk perlindungan dilakukan dengan mengeluarkan Peraturan Daerah (PERDA) Kota Cilegon tentang?

Dalam perlindungan hukum secara preventif pemerintah daerah telah mengatur melalui ketentuan bahwa setiap perusahaan atau industri yang akan berinvestasi di daerah Cilegon harus melaporkan Rencana Penggunaan
Tenaga Kerja (RPTK). ${ }^{35}$ Dengan adanya ketentuan tersebut tentu pemerintah mengetahui kebutuhan dan juga peluang terhadap kesempatan kerja masyarakat lokal atau daerah. Kesempatan kerja masyarakat lokal ditegaskan dalam Pasal 31 bahwa (1) setiap pencari kerja yang terdaftar mempunyai kesempatan yang sama untuk mengisi lowongan pekerjaan; (2) untuk mengisi lowongan sebagaimana dimaksud pada ayat (1), mengutamakan pencari kerja lokal yang memenuhi kualifikasi persyaratan jabatan yang dibutuhkan.

Berlakunya ketentuan tersebut, faktanya tidak berdampak pada menurunnya tingkat pencari kerja atau pengangguran di Kota cilegon sebesar $11,63 \%$. Hal tersebut dimungkinkan oleh makna" pencarikerjalokal adalah pencari kerja yang berdomisili dan memiliki kartu tanda penduduk". ${ }^{36}$ Dengan demikian kesempatan kerja masyarakat lokal atau daerah di mana investasi atau perusahaan industri tersebut dibangun tetap harus berkompetisi dengan penduduk daerah lain di Indonesia.

Makna pencari kerja lokal tentu tidak diperbolehkan ditafsirkan bertentangan dengan ketentuan undang-undang ketenagakerjaan yang menyebutkan setiap tenaga kerja memiliki kesempatan

35 Cilegon, Peraturan Daerah Kota Cilegon No. 2 Tahun 2009 tentang Pelayanan Ketenagakerjaan. Pasal 27.

36 Cilegon. Peraturan Daerah Kota Cilegon No. 6 Tahun 2005 Tentang Pelayanan Ketenagakerjaan Bidang Penempatan dan Pelatihan Tenaga Kerja. Bab 1 Pasal 1 Angka 13. 
yang sama tanpa diskriminasi untuk memperoleh pekerjaan. Akan tetapi pemerintah daerah dalam prinsip otonomi daerah memiliki tanggung jawab terhadap kesempatan kerja masyarakat lokal. Oleh karena itu, pencari kerja lokal dimaknai dengan tenaga kerja yang terdaftar pada dinas tenaga kerja Kota Cilegon.

Mekanisme perekrutan tenaga kerja menurut peraturan daerah Kota Cilegon dalam Pasal 2 untuk penempatan kerja maka "pengguna tenaga kerja dalam pemenuhan tenaga kerja hanya menerima tenaga kerja yang telah terdaftar pada dinas". Hal tersebut menunjukkan adanya pengendalian terkait penempatan kerja bagi perusahaan yang ada di Kota Cilegon melalui dinas ketenagakerjaan. Dengan demikian, seharusnya kesempatan kerja bagi masyarakat lokal sangat terbuka sehingga masyarakat dapat memperoleh kesejahteraan di daerah sendiri.

Fakta yang menunjukkan tingkat pencari kerja atau pengangguran di Kota Cilegon sangat tinggi, dapat dimungkinkan kurangnya penegasan pemerintah daerah terkait pencari kerja lokal. Perlindungan hukum sebagai perlindungan hak setiap masyarakat lokal di Kota Cilegon tidak terpenuhi secara konsisten. Pemerintah Kota
Cilegon memperbolehkan perusahaan untuk mengambil tenaga kerja dari luar daerah apabila para pencari kerja lokal yang terdaftar tidak memenuhi kriteria atau kebutuhan perusahaan atau industri. Hal tersebut tertuang dalam Pasal 4 yang menyatakan "Apabila lowongan pekerjaan yang dimaksud dalam pasal 2 tidak bisa diisi oleh pencari kerja terdaftar pada dinas, maka pengguna tenaga kerja (perusahaan) diperbolehkan memasang iklan di media massa dengan menyampaikan surat pemberitahuan kepada dinas". ${ }^{37}$

Dengan adanya ketentuan tersebut, maka persaingan untuk memperoleh pekerjaan bagi masyarakat lokal semakin tinggi yang memungkinkan tertutupnya peluang kerja bagi masyarakat lokal di Kota cilegon. Dalam era globalisasi saat ini seperti Masyarakat Ekonomi ASEAN (MEA) maupun kerja sama internasional dengan negara lain semakin mempersempit peluang kerja lokal untuk dapat memiliki pekerjaan di daerah sendiri. Untuk itu perlu upaya perlindungan hukum secara represif guna menghindari semakin tingginya tingkat pengangguran bagi masyarakat lokal.

37 Cilegon. Peraturan Daerah Kota Cilegon No. 6 Tahun 2005 Tentang Pelayanan Ketenagakerjaan Bidang Penempatan dan Pelatihan Tenaga Kerja. Bab 2 Pasal 4. 


\section{PENUTUP}

Perlindungan hukum terhadap masyarakat lokal untuk memperoleh kesempatan kerja di daerah sendiri merupakan upaya pemerintah untuk mewujudkan pemerataan kesempatan kerja sesuai amanat konstitusi. Dengan kepastian hukum, maka masyarakat dapat mempertahankan hak-hak mereka untuk memiliki pekerjaan guna terciptanya kesejahteraan bagi masyarakat lokal di daerah sendiri. Kesejahteraan bagi masyarakat merupakan tujuan dari bangsa Indonesia sesuai amanat konstitusi. Memiliki pekerjaan merupakan indikator terpenuhinya kesejahteraan, oleh karena itu untuk menjamin hak tersebut dibentuk perlindungan hukum melalui undang-undang ketenagakerjaan.

Melalui konsepsi Negara hukum maka akan tercipta peluang terselenggaranya kesejahteraan bagi masyarakat (welfarestate). Perlindungan hukum dengan negara kesejahteraan tidak akan terlepas dari konsepsi Negara hukum. Karena kesejahteraan Negara tidak akan tercipta apabila tidak didukung dan dilindungi oleh ketentuanketentuan sebagai landasan pengambilan keputusan dan/atau kebijakan. Dalam prinsip otonomi daerah, maka tanggung jawab kesejahteraan juga dibebankan kepada pemerintah daerah, sehingga kesejahteraan masyarakat lokal dalam kesempatan kerja di daerah perlu mendapat perhatian.

Perlindungan hukum yang diberikan oleh pemerintah daerah adalah bentuk sinergitas antara ketentuan UndangUndang Nomor 13 Tahun 2003 Tentang Ketenagakerjaan serta kewajiban pemerintah daerah dalam memberikan peluang dan kesempatan kerja sebagai bentuk perlindungan kepada tenaga kerja dalam rangka mewujudkan kesejahteraan bagi seluruh masyarakat. Perlindungan masyarakat menjadi salah satu tanggung jawab dan kewenangan pemerintah daerah, termasuk persoalan ketenagakerjaan yang diatur dalam Pasal 12 Ayat (1) huruf e dan Ayat (2) huruf a Undang-Undang Nomor 23 Tahun 2014 Tentang Pemerintah Daerah.

Bentuk perlindungan hukum dapat dilakukan dengan persuasif dan represif, oleh karena itu Pemerintah Daerah Kota Cilegon melakukan upaya secara persuasif dengan mengeluarkan peraturan daerah tentang Pelayanan Ketenagakerjaan Bidang Penempatan dan Pelatihan Tenaga Kerja untuk menjamin hak masyarakat lokal. Namun, secara represif pemerintah tidak memberikan perlindungan hukum secara maksimal sehingga angka pencari kerja masyarakat lokal di Kota cilegon mencapai $11,63 \%$. 


\section{DAFTAR PUSTAKA}

Arrasjid, Chainur. Dasar-Dasar Ilmu Hukum. Ed.1 Cet. Ke-4. Jakarta : Sinar Grafika, 2006.

Asshiddiqie, Jimly. Hukum Tata Negara dan Pilar-Pilar Demokrasi. Ed. Kedua. Cet. Ke-2. Jakarta : Sinar Grafika, 2012.

Astawa, I Gde Pantja dan Suprin Na'a. Memahami Ilmu Negara Dan Teori Negara. Cet. Ke-1. Bandung : Refika Aditama, 2009.

Chandra, Ujang. Karakteristik UndangUndang Ketenagakerjaan Dalam Perlindungan Hukum Terhadap Tenaga Kerja. Jurnal Wawasan Hukum Volume 32, Nomor 1, (2015).

Cilegon. Kota Cilegon Dalam Angka (Cilegon Municipality in Figure) 2016. Katalog/Catalog : 1102001.3672.

Cilegon. "Pengangguran Capai 11,63 Persen, Walikota Cilegon Desak Industri Berdayakan Warga Lokal", https://www.bantennews.co.id/ pengangguran-capai-1163-persenwalikota-cilegon-desak-industriberdayakan-warga-lokall diakses tanggal 9 Desember 2017.

Cilegon. Peraturan Daerah Kota Cilegon No. 6 Tahun 2005 Tentang Pelayanan Ketenagakerjaan Bidang Penempatan dan Pelatihan Tenaga Kerja.
Cilegon. Peraturan Daerah Kota Cilegon No. 2 Tahun 2009 Tentang Pelayanan Ketenagakerjaan.

Ginting, Darwin. "Konsepsi Otonomi Daerah Sebagai Alternatif Pilihan Dari Tuntutan Bentuk Negara Federal Di Indonesia". Jurnal Wawasan Yuridika Volume 25, Nomor 2, (2011).

Indonesia. Peraturan Pemerintah No. 33 Tahun 2013 Tentang Perluasan Kesempatan Kerja.

Indonesia. Undang-Undang Dasar Negara Republik Indonesia 1945.

Indonesia. Undang-Undang No. 13 Tahun 2003 Tentang Ketenagakerjaan

Indonesia. Undang-Undang Nomor 23 Tahun 2014 Tentang Pemerintahan Daerah. Lampiran Undang-Undang Republik Indonesia Nomor 23 Tahun 2014 Tentang Pemerintahan Daerah. Pembagian Urusan Pemerintahan Konkuren antara Pemerintah Pusat dan Daerah Provinsi dan Kabupaten/ Kota. Sub G Pembagian Urusan Pemerintah Bidang Tenaga Kerja.

J. Kaloh. Kepemimpinan Kepala Daerah. Ed.1 Cet. Ke-1. Jakarta :Sinar Grafika, 2009.

Marzuki, Peter Mahmud. Pengantar Ilmu Hukum. Cet. Ke-5. Jakarta : Kencana, 2013. 
Mulyana, Aji. "Perlindungan Hukum Terhadap Perempuan dan Anak Akibat Tindak Pidana Abortus Provocatus Criminalis". Jurnal Wawasan Yuridika Volume 1, Nomor 2, (2017).

Salim dan Erlies Septiana Nurbani. Penerapan Teori Hukum Pada Penelitian Tesis Dan Disertasi. Cetakan Ke-2. Jakarta : Raja Grafindo Persada, 2013.

Santoso, Agus. Menyingkap Tabir Otonomi Daerah Di Indonesia. Cet. Ke-1. Yogyakarta : Pustaka Pelajar, 2013.

Soekanto, Soerjono. Pengantar Penelitian Hukum. Cet. Ke-3. Jakarta : UI Press, 1986.

Soekanto, Soerjono dan Sri Mamuji. Penelitian Hukum Normatif. Ed.1 Cet. 14. Jakarta : Rajawali Press, 2012.

Sunarno, Siswanto. Hukum Pemerintahan Daerah Di Indonesia. Cet. Ke-4. Jakarta: Sinar Grafika, 2012. 